\title{
Quantitative and Qualitative Measurement Methods of Companies' Marketing Efficiency
}

\begin{abstract}
Nowadays, due to ever-changing market conditions, increasingly global market place, and consumer empowerment, one of the main means of marketing accountability, assessment and communication of specific marketing and business objectives in companies are marketing metrics. The authors of this research attempt a critical evaluation of marketing measurement methods by elaborating a conceptual framework of marketing metrics, marketing efficiency, effectiveness, and performance from literature review, as well as implementation of marketing measurement tools in Latvian enterprises in order to gain an overview of current marketing management issue regarding practical marketing assessment. The research paper contains the results of research of the marketing measurement practice in Latvian companies, conducted under the authors' guidance in March, 2014.
\end{abstract}

Keywords: marketing metrics, marketing efficiency, marketing effectiveness, marketing performance measurement, marketing measurement methods.

Dèl nuolat kintančių pasaulinès rinkos sąlygų ir vartotojų išprusimo, viena pagrindinių šiandieninių priemonių, leidžiančių îvertinti įmonių pardavimo atskaitomybę, konkrečius prekybos ir verslo tikslus yra rinkodaros rodikliai. Šio tyrimo autoriai bando kritiškai ịvertinti rinkodaros vertinimo metodus, remdamiesi literatūros apžvalga, siekia parengti rinkodaros rodiklių efektyvumo, veiksmingumo ir panaudojimo koncepcijos modelį, taip pat, tiriant rinkodaros vertinimo ịrankius Latvijos įmonèse, siekia išanalizuoti praktini rinkodaros vertinimą. Straipsnyje pateikiami praktinio rinkodaros vertinimo Latvijos įmonėse $2014 \mathrm{~m}$. kovo menesi atlikto tyrimo rezultatai.

Raktiniai žodžiai: rinkodaros rodikliai, rinkodaros efektyvumas, rinkodaros veiksmingumas, rinkodaros veiklos vertinimas, rinkodaros vertinimo metodai.

\section{Introduction}

Though increasingly more companies recognize the importance of marketing in successful business planning and progress, yet in many cases strategic marketing planning and implementation in business environment is endangered by myopic management (Jeffrey, 2010) or lack of deliberative planning and carefully chosen and tailored set of marketing activities or tools. Myopic management originates the demands for tangible assets and financial evaluation of marketing activities and fast return

Jel̦ena ŠALKOVSKA - lecturer at the University of Latvia, Faculty of Economics and Management. Research areas: marketing management, integrated marketing communications, supply chain management. Phone: +371 29615933. E-mail: jelena.salkovska@lu.lv.

Elina OGSTA - graduate student, University of Latvia, Faculty of Economics and Management. Research areas: marketing management, marketing performance measurement, marketing metrics. Phone: +37126587964 . E-mail: elinaogsta@gmail.com E-mail: elinaogsta@gmail.com. 
on investment (ROI) or, more specifically, return on marketing investment (ROMI). Common viewpoint considers marketing as costs, although these expenses should be treated as medium-term and long-term investments; this aspect shows one of the main marketing problems - economic justification. Even if top management increases marketing investment, marketers keep struggling with delivery of tangible marketing results back to the board room. Nowadays marketers face many challenges in an increasingly complex marketplace and addressing the wide range of stakeholders - prospects, customers, shareholders, partners, and vendors (Gao, 2010). Therefore the scientific problem of this research is: which marketing efficiency, effectiveness, and performance aspects at companies in Latvia are being evaluated, measured, and brought to attention. Defining the value and management of each asset is a critical task and an important step toward the improvement of the return on marketing investment (ROMI) which can and should be achieved with appropriately chosen marketing metrics and marketing efficiency measurement methods as it is then possible to evaluate whether marketing activity plays a role in driving base sales evaluation (Chain, 2011).

The aim of the article is to analyse various levels and categories of marketing measurement methods, grounding this analysis in literature review, as well as to study the current state of marketing measurement practice in Latvian enterprises.

\section{Tasks of the research are:}

1. To consider the point of matter of marketing measurement, marketing metrics, marketing efficiency, effectiveness and performance;

2. To survey representatives of Latvian companies about marketing measurement, offering to evaluate 57 marketing metrics and the usefulness of each metric in individual strategic business and marketing planning and realization situation;

3. To evaluate the overall usage of marketing metrics in Latvian enterprises and to mark out the widely used and rarely used metrics;

4. To develop the possible ground for improvement of marketing measurement strategy of Latvian companies in order to gain marketing accountability and better overall competitive advantage.

The research object: quantitative and qualitative marketing measurement methods.

Research objectives: the current state of marketing measurement implementation in Latvian companies and the assessment of marketing managers' knowledge of various marketing metrics within marketing management and control processes.

Research methods: literature analysis, quantitative research, survey method questionnaire of marketing representatives of Latvian companies.

During the research the authors focused on different categories of marketing metrics that helped to measure marketing performance and marketing efficiency. The authors also analysed difficulties that are linked with the usage of such metrics and methods, which are stemming from the lack of knowledge or ability to substantiate to the management the need for such metric usage, thus eliminating the danger of myopic management that aims mostly on short-term goals. The task was to ground the research on Latvian companies and their practice, thus enabling a further proposition of possible options for the usage of measurement methods in different industries, markets, and amount of 
marketing investments, also to show how relevant it can be to business and marketing strategy measuring not only tangible performance indicators, but also nonfinancial ones.

The research has practical value - it allows evaluating current situation, draws suggestions for further research, and helps marketers to gain more knowledge and demonstrate marketing efficiency and effectiveness to stakeholders.

\section{Marketing measurement methods - marketing metrics}

A metric is a performance measure that the company's management should review and evaluate on regular basis in the most suitable way. Mostly marketing metrics are defined as strategically designed set of marketing measurement and evaluation methods (Table 1). Usage of marketing metrics is considered being an important part of marketing evaluation and control process (Cravens, Piercy, 2003; Kumar, 2004; Farris et al., 2010; Jeffrey, 2010); metrics should be dynamic and evolve alongside business developments (McDermott, 2013). Great importance lies within understanding that metric is not just another word for measure: metrics should be always relevant, precise, consistent, and sufficient for review purposes (Ambler, 2002).

The significance of marketing metrics arises from the expectation that a company will prosper if it has a well and clear defined strategy and business model, thus marketing metrics are strategically important for progress assessment. They serve as indicators of future cash flow in the market, as well as of the current cash flow. Marketing metrics are helpful in future marketing and business plan development, by evaluating previous marketing activities and designing new ones.

Also the importance of marketing metrics and the data such metrics can provide

\section{Definitions of marketing metrics}

Table 1

\begin{tabular}{|c|c|c|}
\hline No. & Authors & Definition \\
\hline 1. & T. Ambler (2000) & $\begin{array}{l}\text { Market (or marketing) metrics are a range of measures of different aspects of } \\
\text { brand strength and marketing performance with aim to align measurement (and } \\
\text { behaviour) with strategic goals, to make marketing more accountable, and to } \\
\text { provide diagnostic information for top management decision making. }\end{array}$ \\
\hline 2. & $\begin{array}{l}\text { R. Shaw, } \\
\text { D. Merrick (2005) }\end{array}$ & $\begin{array}{l}\text { Marketing metric is a numerical summary of observations carried out on a regu- } \\
\text { lar basis according to agreed standards of observation and marketing analysis. }\end{array}$ \\
\hline 3. & $\begin{array}{l}\text { P. W. Farris et al. } \\
(2010)\end{array}$ & $\begin{array}{l}\text { A metric is measuring system that quantifies a trend, dynamic, or characteristic. } \\
\text { Marketers require marketing metrics in order to justify in numeric terms the } \\
\text { financial risks, benefits of decisions, to evaluate plans, explain variances, judge } \\
\text { performance, and identify leverage points for improvement. }\end{array}$ \\
\hline 4. & Y. Gao (2010) & $\begin{array}{l}\text { The performance indicators that top management use (or should use) to track } \\
\text { and assess the progress - specifically the marketing performance - of a business } \\
\text { or business unit. }\end{array}$ \\
\hline 4. & $\begin{array}{l}\text { Marketo, Inc. } \\
(2011)\end{array}$ & $\begin{array}{l}\text { Marketing metrics are used in a measurement system, used by marketers to track } \\
\text { and measure the impact of all key marketing activities, both hard and soft. }\end{array}$ \\
\hline 5. & $\begin{array}{l}\text { Ph. Kotler, K. L. } \\
\text { Keller (2012) }\end{array}$ & $\begin{array}{l}\text { Marketing metrics is the set of measures that helps marketers to quantify, com- } \\
\text { pare, and interpret their marketing performance. }\end{array}$ \\
\hline
\end{tabular}

Source: the authors' summary. 
to marketers and managers lies within cognition that nowadays marketers alter budgets from traditional to digital channels, they need to be able to determine the optimal spend across multiple channels in order to be more accountable to the top management. With the ability to measure, marketing can have an accounting value (McDermott, 2013). This factor enables marketers to translate marketing costs into associated revenue; by breaking down each marketing channel marketers can look at past returns from past marketing activities and set new goals for return on marketing investment (ROMI) they hope to achieve from going forward. When linking marketing to shareholder value and financial performance, marketers cannot afford to forget to balance indicators of past financial health - financial metrics - and indicators of potential financial health - marketing metrics (Kumar, 2004)

Although marketing metrics are gaining more attention as an important part of marketing measurement and evaluation process, and despite contributions on the subject marketing metrics researchers (Bonoma, Clark, 1988; Ambler, 2000, 2002; Rust et al., 2004; Barwise, Farley, 2004; Moeller, Landry, 2008; Farris et al., 2010), the marketing performance and marketing efficiency measurement studies could be expanded by offering structured process or framework for organization of the marketing measures. Marketing metrics researchers offer various ways how to categorize these measurement methods and point out mostly used metrics (Table 2). T. Ambler and D. Riley (2000) identified the 19 most widely used metrics for internal evaluation of marketing performance and brand equity; M. Jeffrey (2010) suggests to concentrate on as few metrics as possible that capture the most value for marketing and he proposes 15 essential marketing metrics; P. W. Farris et al. (2010) offer 11 main groups of more than 50 marketing metrics, characterized with central issues addressed by these metrics.

If we examine each marketing metric and the information it provides for a company, the way such information should be treated, marketing metrics can be characterized as quantitative (hard metrics) and qualitative (soft metrics), thus the authors propose following classification of metrics:

1. Quantitative marketing measurement metrics - evaluates tangible assets and can be more easily expressed in monetary value, count, percentage. Such metrics are: customer count, sales, gross margins, profitability, market share, penetration, net profit, economic profit (EVA), net present value (NPV), payback, internal rate of return (IRR), impressions, cost per click (CPC), net reach, baseline sales, promotion lift, customer lifetime value (CLV), etc.

\section{Qualitative marketing measure-} ment metrics - evaluates intangible assets which over the last 40 years have become more significant as drivers of market value (Ocean Tomo, LLC, 2011). These metrics indirectly derive at value; value is not always about money, instead, it is also focused around consumer reactions. Such metrics are: loyalty, awareness, likeability, satisfaction, word of mouth (WOM), willingness to search, willingness to recommend, perceived quality, etc.

There are many metrics for marketers to choose from and they must keep in mind that there is not a one "golden" metric or even a group of such metrics, suitable for all companies and all business situations. Differences in forms of marketing 
Metrics categorization by competent researchers

Table 2

\begin{tabular}{|c|c|c|}
\hline Researchers & Metrics categories & Main marketing metrics \\
\hline \multirow{6}{*}{$\begin{array}{l}\text { T. Ambler, D. } \\
\text { Riley (2000) }\end{array}$} & $\begin{array}{l}\text { 1. Consumer } \\
\text { intermediate }\end{array}$ & $\begin{array}{l}\text { 1. Awareness; perceived quality; consumer satisfaction; rele- } \\
\text { vance to consumer; perceived differentiation; brand/product } \\
\text { knowledge. }\end{array}$ \\
\hline & 2. Consumer behaviour & 2. Number of new customers; loyalty/retention; conversions. \\
\hline & 3. Trade consumer & 3. Customer satisfaction; number of complaints. \\
\hline & 4. Relative to competitor & 4. Relative consumer satisfaction; perceived quality. \\
\hline & 5. Innovation & $\begin{array}{l}\text { 5. Number of new products; revenue of new products; margin } \\
\text { of new products. }\end{array}$ \\
\hline & 6. Financial & 6. Sales; gross margins; profitability. \\
\hline \multirow{5}{*}{$\begin{array}{l}\text { N. Kumar } \\
(2004)\end{array}$} & 1. Products & $\begin{array}{l}\text { 1. Relative product quality; perceived product quality; percen- } \\
\text { tage of sales from new products; product profitability. }\end{array}$ \\
\hline & 2. Brands & $\begin{array}{l}\text { 2. Brand awareness; brand esteem; brand loyalty; brand } \\
\text { profitability. }\end{array}$ \\
\hline & 3. Channels & $\begin{array}{l}\text { 3. Channel penetration; channel trust; channel efficiency; } \\
\text { market share in each channel; channel profitability; shelf } \\
\text { space. }\end{array}$ \\
\hline & 4. Customers, segments & $\begin{array}{l}\text { 4. Customer satisfaction; average transaction size; customer } \\
\text { complaints; customer acquisition costs; customer retention } \\
\text { rate; customer profitability. }\end{array}$ \\
\hline & 5. Markets & $\begin{array}{l}\text { 5. Market penetration; market share; sales growth; market } \\
\text { profitability. }\end{array}$ \\
\hline \multirow{9}{*}{$\begin{array}{l}\text { P. W. Farris et } \\
\text { al. (2010) }\end{array}$} & $\begin{array}{l}\text { 1. Share of hearts, minds } \\
\text { and markets }\end{array}$ & $\begin{array}{l}\text { 1. Awareness; knowledge; hierarchy of effects; loyalty; willin- } \\
\text { gness to recommend; market share; brand penetration, etc. }\end{array}$ \\
\hline & 2. Margins and profits & $\begin{array}{l}\text { 2. Unit margin; channel margins; contribution per unit; target } \\
\text { volume; break-even sales, etc. }\end{array}$ \\
\hline & $\begin{array}{l}\text { 3. Product portfolio } \\
\text { management }\end{array}$ & $\begin{array}{l}\text { 3. Repeat volume; penetration; cannibalization rate; brand } \\
\text { equity; conjoint utilities; volume projections, etc. }\end{array}$ \\
\hline & 4. Customer profitability & 4. Customers; retention rate; customer lifetime value, etc. \\
\hline & $\begin{array}{l}\text { 5. Sales force and chan- } \\
\text { nel management }\end{array}$ & $\begin{array}{l}\text { 5. Sales; sales pipeline; markdowns; workload; compensation; } \\
\text { sales force effectiveness; total distribution, etc. }\end{array}$ \\
\hline & 6. Pricing strategy & 6. Price premium; reservation price; percent good value, etc. \\
\hline & 7. Promotion & $\begin{array}{l}\text { 7. Baseline sales; incremental sales; promotion lift; redemption } \\
\text { rates, etc. }\end{array}$ \\
\hline & $\begin{array}{l}\text { 8. Advertising media } \\
\text { and web metrics }\end{array}$ & $\begin{array}{l}\text { 8. Impressions; cost per click; click-through rate; net reach; } \\
\text { average frequency; cost per } 1000 \text { impressions, etc. }\end{array}$ \\
\hline & $\begin{array}{l}\text { 9. Marketing and } \\
\text { finance }\end{array}$ & $\begin{array}{l}\text { 9. Net profit; return on investment (ROI); economic profit } \\
\text { (EVA); net present value (NPV); return on marketing inves- } \\
\text { tment (ROMI), etc. }\end{array}$ \\
\hline $\begin{array}{l}\text { M. Jeffrey } \\
(2010)\end{array}$ & - & $\begin{array}{l}\text { Brand awareness; test-drive; churn; customer satisfaction; } \\
\text { take rate; profit; net present value (NPV); internal rate of } \\
\text { return (IRR); payback; customer lifetime value (CLV); cost } \\
\text { per click (CPC); transaction conversion rate (TCR); return on } \\
\text { advertising money spent (ROA); bounce rate; word of mouth } \\
\text { (WOM). }\end{array}$ \\
\hline
\end{tabular}

Source: the authors' summary, with reference to T. Ambler, D. Riley (2000), N. Kumar (2004), P. W. Farris et al. (2010), M. Jeffrey (2010). 
tools, channels and messages used and the way they have been used may make harder application of different metrics, but for better marketing management, implementation, and control authors suggest that companies should apply both quantitative, and qualitative marketing performance measurement methods with past, present, and future (desirable) performance assessment.

N. Kumar (2004) points out the corporate nature of marketing metrics as characteristic, common in large enterprises and companies by saying "Corporate marketing can influence the definition of the relevant marketing metrics at each of the five levels of business (products, brands, channels, customers, markets) and ensure that each division and country tracks, collects, and reports the appropriate metrics using a common methodology so that executives can compare data across the firm" (Kumar, 2004). Nevertheless more recently researchers have pointed out that different metrics can be used in variously profiled companies for wide range of purposes within marketing-mix model - different media (social, print, television, etc.), marketing activities (campaigns, promotions, sponsorships, etc.), channels and so on (Farris et al., 2010;
Smit, Neijens, 2011; Flores, Struyk, 2012; Bauer Marshall, 2013; Bhattachary, Mehta, 2013). Also the study of current situation in Latvia shows that such metrics are gaining increasing acknowledgement and are used even in small companies, as well as in medium firms and large enterprises, although some gaps in marketers' and executives' knowledge can be noticed.

The authors offer the readers a review of marketing efficiency, effectiveness, and marketing performance definitions and characterizations in order to gain better understanding about these different aspects of marketing management and implementation process.

Over the time marketing efficiency, effectiveness, and performance have attracted great deal of attention in academic literature and within managerial staff of companies. Marketing literature and other publications on marketing issues address these concepts in various ways (Tables 3 and 4).

As it has been pointed out in literature, marketing must focus on delivering effective efficiency: delivering greater value to customers and the corporation at lower cost (Sheth, Rajendra, 2002). Both efficiency and effectiveness are critical to marketing performance.

\section{Definitions of marketing efficiency}

Table 3

\begin{tabular}{|c|l|l|}
\hline No. & \multicolumn{1}{|c|}{ Authors } & \multicolumn{1}{c|}{ Definition } \\
\hline 1. & $\begin{array}{l}\text { T. Ambler et al. } \\
(2001)\end{array}$ & The ratio of results to resources used, e.g. return on investment. \\
\hline 2 & $\begin{array}{l}\text { R. Shaw, D. Mer- } \\
\text { rick (2005) }\end{array}$ & $\begin{array}{l}\text { Marketing efficiency is usually measured as a ratio of outputs to inputs, for } \\
\text { example, direct mail response rate is a measure of efficiency. }\end{array}$ \\
\hline 3. & Y. Gao (2010) & $\begin{array}{l}\text { Doing things right. Comparisons of output from marketing to input of } \\
\text { marketing. }\end{array}$ \\
\hline 4. & $\begin{array}{l}\text { Marketo, Inc. } \\
(2011)\end{array}$ & $\begin{array}{l}\text { Efficiency is more likely to produce questions from the CFO and other financi- } \\
\text { ally-oriented executives than effectiveness; efficiency marketing metrics will be } \\
\text { no defence against efforts to prune marketing budget in difficult times. }\end{array}$ \\
\hline
\end{tabular}

Source: the authors' summary. 
Definitions of marketing effectiveness

Table 4

\begin{tabular}{|c|l|l|}
\hline No. & \multicolumn{1}{|c|}{ Authors } & \multicolumn{1}{c|}{ Definition } \\
\hline 1. & T. Ambler et al. (2001) & $\begin{array}{l}\text { The extent to which marketing actions have moved the company towards } \\
\text { its goals. }\end{array}$ \\
\hline 2. & T. Ambler (2004) & $\begin{array}{l}\text { Marketing effectiveness is the quality of how marketers go to market with } \\
\text { the goal of optimizing their spending to achieve good results for both the } \\
\text { short-term and long-term. }\end{array}$ \\
\hline 3. & F. T. Mavondo (2005) & $\begin{array}{l}\text { The ability of the organisation to meet short-term goals that might positi- } \\
\text { vely impact financial performance such as increasing market share, incre- } \\
\text { asing sales, improving gross margin, successful new product introduction. }\end{array}$ \\
\hline 4. & $\begin{array}{l}\text { N. G. Nwokah, } \\
\text { A. I. Ahiauzu (2008) }\end{array}$ & $\begin{array}{l}\text { The extent to which an organisation acquires market share over competi- } \\
\text { tors, advertising and promotional share of the market. }\end{array}$ \\
\hline 5. & $\begin{array}{l}\text { N. G. Nwokah, } \\
\text { A. I. Ahiauzu (2009) }\end{array}$ & $\begin{array}{l}\text { Function of improving how marketers go to market with the goal of opti- } \\
\text { mizing their marketing spend to achieve even better results for both the } \\
\text { short-term and long-term objectives. }\end{array}$ \\
\hline 6. & Y. Gao (2010) & $\begin{array}{l}\text { Doing the right thing. Comparisons of performance to the goals formula- } \\
\text { ted from the market strategy. }\end{array}$ \\
\hline 7. & $\begin{array}{l}\text { R. Pramaniak, } \\
\text { G. Prakash (2010) }\end{array}$ & $\begin{array}{l}\text { Ration among difference between consumers price and producers price, } \\
\text { and marketing cost. }\end{array}$ \\
\hline 8. & Marketo, Inc. (2011) & $\begin{array}{l}\text { Effectiveness convinces sales, finance and senior management that marke- } \\
\text { ting delivers quantifiable value. }\end{array}$ \\
\hline
\end{tabular}

Source: the authors' summary based on I. Daukševičiūté et al. (2011).

Marketing performance is characterized as a multidimensional process that includes the three dimensions of effectiveness, efficiency and adaptability; the effectiveness and efficiency of an organisation's marketing activities with regard to market-related goals, such as revenues, growth, and market share (Gao, 2010). To understand marketing performance, multiple measures are needed because marketing performance pertains to customer acquisition and retention which is one of the main business objectives for majority of companies.

\section{Research - usage of marketing metrics in companies in Latvia}

In order to get an insight into marketing metrics application practice and to make observations and find coherence between other business aspects such as number of customers, marketing budget, growth rate in sales etc. in Latvian companies', in March 2014 the survey was conducted by handing the questionnaire personally by authors, as well as by sending the online questionnaire to 796 marketing specialists of Latvian companies; the major population of the research span 11966 small, mid-sized and large businesses (Statistical Enterprise Register, 2014).

104 responses were received, a response rate of $13.1 \%$. Representatives of companies were chosen by simple random sample method from data bases. The sample of respondents was intended as representative of full range of industrial sectors, but, as results show, some industries were covered more than others (e.g. retail, wholesale, and services, financial services, 
information technologies, food and drink manufacturing).

The questionnaire addressed the following core issues:

1. The characteristics of companies (industry, markets by territory, what company offers to markets and what characterizes their customers);

2. Usage of internet communication channels and social media;

3. Evaluation of importance for business managing and monitoring of 57 marketing metrics, given in no particular order; choices - very important, important, not sure, not useful, metric is not used at all;

4. The changes in customer count over the last year; the changes in marketing budget over the last year; the growth rate in sales over the last three years;

5. Marketing planning, implementation and evaluation and managing personnel (marketing activities are planned for what period of time; how often marketing audit is performed; who is planning marketing activities in company?).

Main trends and information derived from the survey $-34 \%$ of all respondents represented large companies (characterized as companies with more than 250 employees); $27 \%$ - mid-sized (50-249 employees); $24 \%$ - small businesses (10-49 employees), and $14 \%$ represented microbusinesses (up to 9 employees). The most represented industries in the research are trade and services (31\%) and financial services (16\%). $47 \%$ of respondents offer customers both products, and services; $54 \%$ deals with both business, and private customers. The most common internet communication channels are company's web page (32\%) and Facebook (23\%); $15 \%$ of Latvian companies use Twitter, but $3 \%$ said that they do not use any of internet communication channels.
Given the possibility to choose more than one option, respondents indicated that most of the companies operate in Latvia (32\%); only in capital Riga operate $15 \%$ of respondents; Europe - $18 \%$; CIS countries $-14 \%$; $11 \%$ of the respondent companies operate in global markets (most of them are global companies with franchises or agencies in Latvia); $3 \%$ Asia; $7 \%$ are running their businesses in regions of Latvia, majority of them are micro-companies. These results allow concluding that companies in Latvia are operating in different markets, they are adaptive to different scopes and thus the need for marketing efficiency measurement methods should be apprehended.

The research clearly shows the importance for companies in Latvia to measure mainly financial performance, more concentrating on tangible assets like customers, net profit, return on sales, etc. (see Figure 1). From marketing metrics that measure intangible performance measures, highly evaluated is customer satisfaction correlation exists between service culture in Latvia overall as customer service is widely appreciated and encouraged (e.g. every year March is Services Awareness month), thus it is widely acknowledged that the best service companies in Latvia tend to thrive and gain better reputation which leads to better sales, greater market share, superior net profit, and other critical to businesses sets of measures. Study also indicates that companies in Latvia tend to assess customers' willingness to search and willingness to recommend - two metrics that are also linked with brand and/or new product development possibilities, present and future cash flows. These metrics can tell a company much about the attitudes of its customers and whether its position in the market is defensible against pressure from 


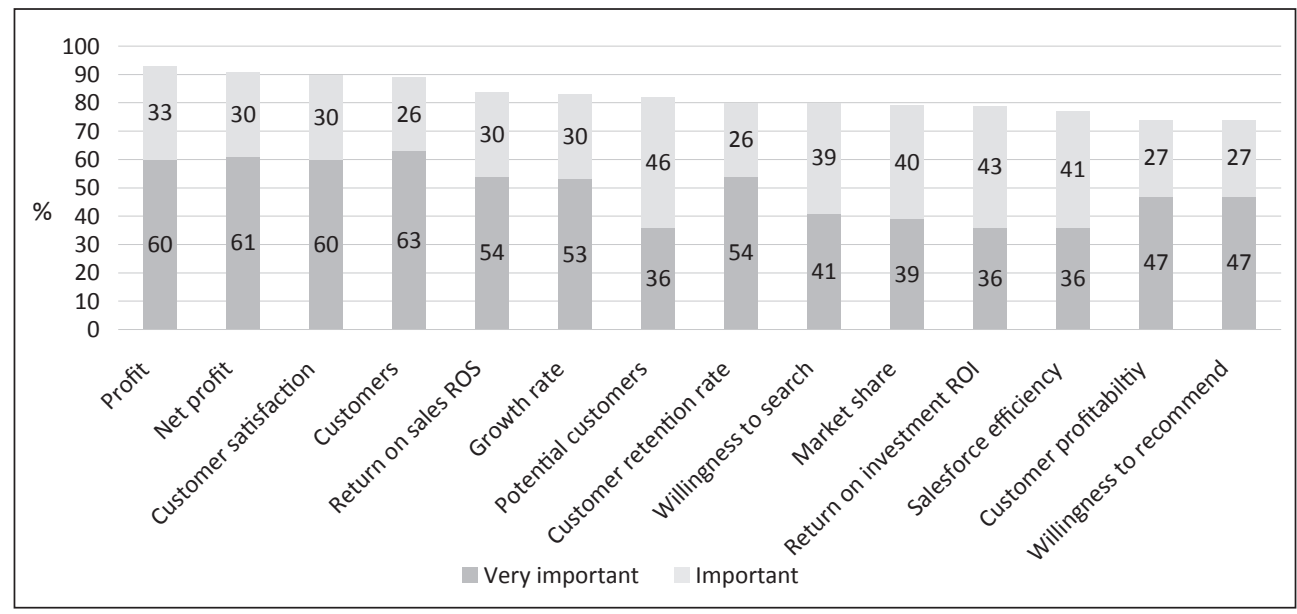

Fig. 1. Marked out as most widely used marketing metrics in Latvian companies

Source: according to the results of the survey carried out by the authors in March 2014.

competitors; if customer is satisfied with a product, customer is more likely going to recommend it to friends, relatives, and colleagues, thus increasing the competitive advantage of a company (Farris et al., 2010).

Regarding social presence via various internet communication channels and tools, it can be assumed that companies acknowledge the need for social presence, but not so many of them evaluate the financial value added to business from usage of such communication, for example, the impact of word of mouth (WOM); nevertheless this aspect may be addressed in further studies. There are elements of the marketing and communications mix that do provide rich customer-level data and return on investment. Social media programs are highly targeted, measurable, and effective, but company should not rest of marketing tools just because they seemingly do not provide return on investment. As study shows, many companies in Latvia focus on different social and internet platforms as their marketing communication tools, but not so many companies realizes the importance of social presence, and therefore it is not measured in any way.

Figure 2 shows the most confusing marketing metrics for Latvian marketing specialists, managers and executives, these metrics are not used in companies at all or respondents have indicated that they are not sure whether such metric is important for their marketing performance assessment. The real problem might be that most companies struggle to draw conclusions from positive results in intangible asset studies from their market to their businesses.

Marketing efficiency and company performance are assessed better if marketing metrics complement traditional financial metrics. Particularly, marketing metrics can work as leading indicators of problems, opportunities, and future financial performance. Study shows that in $70 \%$ respondent companies over the last year have acquired more customers and thus have the opportunity to gain 


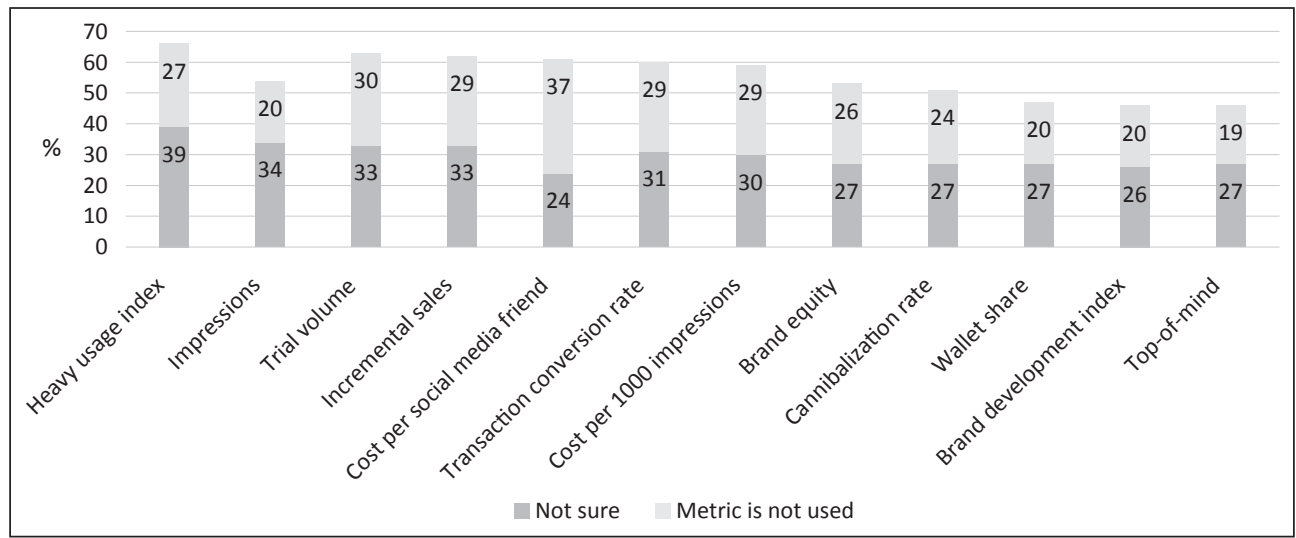

Fig. 2. Marked out as most rarely used marketing metrics for Latvian companies

Source: according to the results of the survey carried out by the authors of the article in March 2014.

better competitive advantage, but at the same time marketing budget has not been aligned to the expanding customer base, leading marketers to work with larger customer scope with the same or not equally increased budget. Figure 3 shows the percentage of the best business performances and the link between marketing budget and growth rate in sales in Latvian companies. The coherence between these indicators may be treated as marketing specialists' ability to spend less and create greater value; as well as their inability to substantiate need for increased budget.

The major questions to be frequently asked in order to assess the marketing performance and efficiency are given in Figure 4. Marketing specialists must have clear answers to these questions, analyzing such aspects frequently and systematically. It will help to choose adequately marketing metrics that can work for indicating and treating issues that endanger the overall health of business.

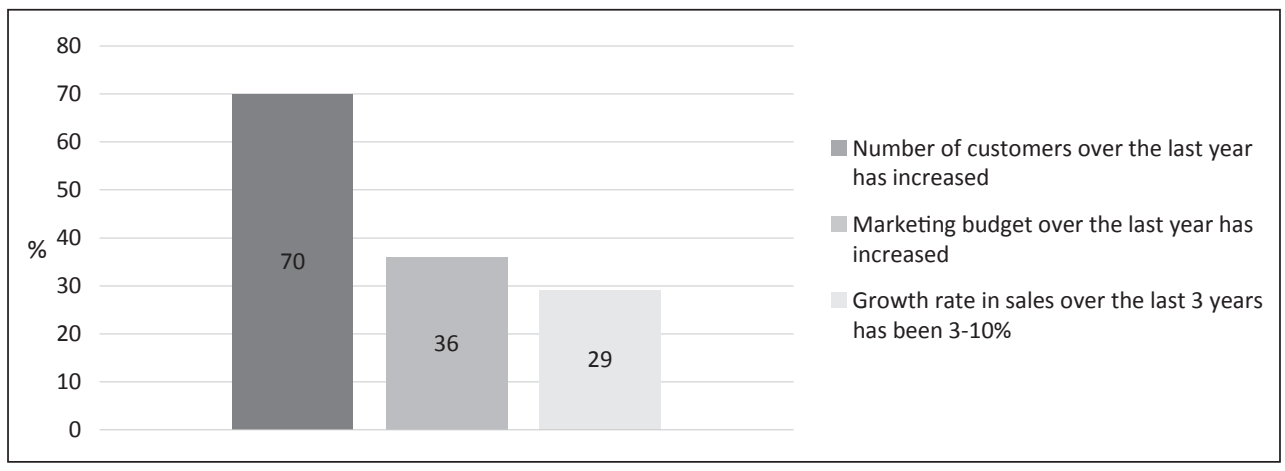

Fig. 3. The coherence between number of customers, growth rate in sales and marketing budget

Source: according to the results of the survey carried out by the authors of the article in March 2014. 


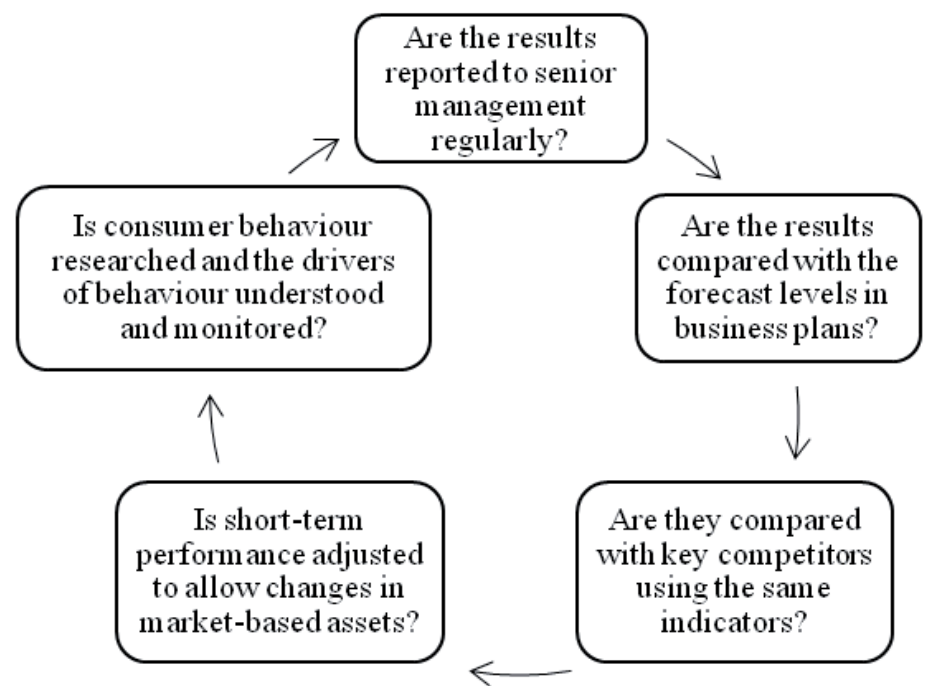

Fig. 4. Questions for assessing adequacy of marketing performance and efficiency measurement methods

Source: the authors' proposal with reference to T. Ambler (2000).

This study was an expedient first stage for further research as it gave a substantial insight into current situation in Latvia how marketing metrics tend to be used in Latvian companies, as well as showed significant links between marketing metrics' application and marketing planning, implementation, and overall management process. Based on gathered data, ongoing research phases may be developed in a particularly corresponding way. Research also can be considered as important tool for raising overall awareness about marketing metrics between marketing specialists in Latvian firms - as authors via questionnaire proposed for companies to assess 57 different marketing metrics, many of them as a result were marked out as less known, authors hope this marketing specialists' obscurity at some point will encourage them to inquire more information and current knowledge about marketing metrics and bring more value to their businesses.

\section{Conclusions and proposals}

Based on the conducted research, the authors make the following conclusions:

1. Marketing metrics over the last decades have gained more attention in academic circles, yet marketing performance and marketing efficiency measurement in practice is vaguer as survey of Latvian companies' shows - marketing representatives from 104 in many cases strive to understand or know various marketing metrics form 57 proposed.

2. Three different perspectives are taken into account when measuring and evaluating marketing performance - efficiency, effectiveness, and adaptability. The contribution of marketing on overall business performance and shareholder value is evaluated in terms of five levels of impact - the company, customer, market, financial and shareholder. All of these approaches and levels of measurement are 
incorporated in marketing performance measurement system.

3. Nowadays business objective is to develop comprehensive, credible and adaptable marketing performance measurement system.

4. Marketing efficiency and company performance are assessed better if marketing metrics complement traditional financial metrics. Particularly, marketing metrics can work as leading indicators of problems, opportunities, and future financial performance.

5. Latvian enterprises are more focused on measuring finance outcomes, but there can be observed a tendency of endeavours to measure harder measurable aspects of marketing performance, such as formed customer attitudes, beliefs and willingness to recommend or search.

6. Financial results in many cases have little to do with sustainable and long-term business development, therefore Latvian companies also acknowledge the necessity to assess customer beliefs, attitudes, and behaviour by measuring the customer satisfaction level, willingness to search and willingness to recommend.

Based on the conducted research, the authors offer the following proposals:

1. Future research must be conducted; it should focus on methodological base of calculations of marketing metrics, as well as specific empirical investigation of marketing effectiveness and efficiency in Latvian companies must be carried out by implementation of in-depth interviews and more specifically adapted survey.

2. In order to evaluate the overall marketing performance, a multidimensional set of marketing metrics is required, including both financial and non-financial measures that address both marketing inputs and outputs. These measures need to be evaluated against both internal and external (if possible) benchmarks, adjusted for the effects brought forward from past and carried forward for future periods.

3. The companies must keep in mind that there is no universal, one set of marketing metrics, suitable for all companies in one industry or in one market - the right metrics depend upon the specifics of what marketing function is held accountable for and the most-critical questions for which marketing needs to be responsible.

4. Companies in Latvia should focus on measuring what is the most relevant to them, not only what they can measure as one gets what is measured, companies must identify the key indicators which are utmost important for sustainable and long-term development.

5. Usage of marketing metrics is considered being an important part of marketing evaluation and control process and it is important to understand that marketing metric is not just another word for measure: metrics must be relevant, precise, consistent, and sufficient for review and analysis purposes for companies in order to gain better understanding about markets, customers, business and value drivers.

6. By the following qualitative study (in-depth interviews, case studies etc.) and communication with respondents from Latvian companies would ensure that overall level of awareness about marketing metrics and opportunities they offer to businesses and the value they can create is raised.

7. The authors acknowledge that there are country-specific differences in the use of marketing metrics (e.g. what works in USA, doesn't work in Latvia); therefore, 
through further research a framework of marketing metrics, suitable for Latvian enterprises, should be developed.

8. Marketing measurement is a comprehensive and ever continuing marketing evaluation and control process as companies must adapt to changing market situations, so they must be able to adapt their set of suitable marketing metrics to changes in current situation, keeping in focus the overall business objectives and marketing role within a company.

\section{References}

1. Ambler, T. (2000). Marketing and the Bottom Line: The New Metrics of Corporate Wealth. London: FT Prentice Hall.

2. Ambler, T., Riley, D. (2000). Marketing Metrics: A Review of Performance Measures in Use in the UK and Spain. - Report No. 00-500, Cambridge, MA, Marketing Science Institute.

3. Ambler, T., Kokkinaki, F., Puntoni, S., Riley, D. (2001). Assessing Market Performance: The Current State of Metrics. - Working Paper. No. 01-903, London Business School, Centre of Marketing.

4. Ambler, T. (2002). Market Metrics: What Should We Tell the Shareholders? // Balance Sheet. Vol. 10, Issue 1, pp. 47-50. doi: http://dx.doi. org/10.1108/09657960210697418.

5. Ambler, T. (2004). Marketing and the Bottom Line: The Marketing Metrics to Pump up Cash Flow. - London: Financial Times Press.

6. Barwise, P., Farley, J. U. (2004). Marketing Metrics: Status of Six Metrics in Five Countries // European Management Journal. Vol. 22, No. 3, pp. 257-262. doi: http://dx.doi.org/10.1016/j. emj.2004.04.012.

7. Bauer Marshall, S. (2013). Increase Return on Marketing Investments by Measuring the Previously Unmeasurable. Audience Measurement 8.0. Internet access: <http://www.warc.com/ Home.aspx>, [accessed February 10, 2014].

8. Bhattachary, P., Mehta, K. (2013). RapidMMM: Richer, Faster and Affordable Marketing Mix Models. - Paper presented at the ARF Experiential Learning, Re:Think Conference. Internet access: <http://www.warc.com/Home.aspx>, [accessed February 10, 2014].

9. Bonoma, T.V., Clark B. H. (1988). Marketing Performance Assessment. - Boston: Harvard Business School Press.
10. Chain, P. (2011). Modelling the Real Return on Marketing Investments // Marketing NPV Journal. Vol. 7, Issue 3, pp. 15-19. Internet access: <http://issuu.com/marketingnpv/docs/ modeling_the_real_return_on_marketing_inv estments_?mode $=$ embed $\&$ layout $=$ http $\% 3 \mathrm{~A} \% 2$ F\%2Fskin.issuu.com\%2Fv\%2Fdark\%2Flayout. $\mathrm{xml}>$, [accessed March 15, 2014].

11. Cravens, D. W., Piercy, N. F. (2003). Strategic Marketing: $7^{\text {th }}$ Edition. - New York: McGrawHill/Irwin.

12. Cook, W., Talluri, V. (2004). How the Pursuit of ROMI Is Changing Marketing Management? // Journal of Advertising Research. Vol. 44, Issue 3, pp. 244-254. Internet access: <http://www.journalofadvertisingresearch. c o m / A r t i cle C enter/d ef a u l t . asp $?$ ID $=80295 \&$ Type $=$ Article $>, \quad$ [accessed February 21, 2014].

13. Daukševičiūte, I., Valainis, A., Vilkaite, N. (2011). Conceptualization of the Effectiveness of Marketing Tools // Intellectual Economics. Vol. 5, No. 2, pp. 200-211. Internet access: <https:// www3.mruni.eu/ojs/intellectual-economics/ article/view/814>, [accessed February 21, 2014].

14. Farris, P. W., Bendle, N. T., Pfeifer, P. E., Reibstein, D. J. (2010). Marketing Metrics: 50+ Metrics Every Executive Should Master, $2^{\text {nd }}$ Edition. - New Jersey: Pearson Education, Inc.

15. Flores, L., Struyk, K. (2012). Perceived Value of Facebook Fans: Measurement and Accountability. Paper presented atARF Experiential Learning, Re:Think Conference. Internet access: <http://www.warc.com/Home.aspx>, [accessed February 10, 2014].

16. Gao, Y. (2010). Measuring Marketing Performance: a Review and a Framework //The Marketing Review. 10(1), pp. 25-40. doi: http://dx.doi. org/10.1362/146934710X488924. 
17. Jeffrey, M. (2010). Data-Driven Marketing: The 15 Metrics Everyone in Marketing Should Know. - New Jersey: Wiley \& Sons, Hoboken.

18. Kotler, Ph., Keller, K. L. (2012). Marketing Management: 14e Global Edition. - Harlow: Pearson Education Limited.

19. Kumar, N. (2004). Marketing as Strategy: Understanding the CEO's Agenda for Driving Growth and Innovation. - Boston: Harvard Business School Press.

20. McDermott, M. J. (2013). Actionable Analytics: Reexamining Metrics for Better Data-Driven Decisions // ANA Magazine, Fall 2013. Internet access: <http://www.warc.com/Home.aspx>, [accessed February 10, 2014].

21. Marketo, Inc. (2011). The Definite Guide: Marketing Metrics \& Analytics. Internet access: <http://www.marketo.com/definitive-guides/ marketing-metrics-and-marketing-analytics/>, [accessed January14, 2014].

22. Mavondo, F. T. (2005). Learning Orientation and Market Orientation // European Journal of Marketing. Vol. 39, Issue 11, pp. 1235-1263. doi: http://dx.doi.org/10.1108/03090560510623244.

23. Moeller, L. H., Landry, E. C. (2008). The Four Pillars of Profit-Driven Marketing: How to Maximize Creativity, Accountability, and ROI. New York: McGraw-Hill.

24. Nwokah, N. G., Ahiauzu, A. I. (2008). Managerial Competencies and Marketing Effectiveness in Corporate Organizations in Nigeria // Journal of Management Development. Vol. 27, Issue 8 , pp. 858-878. doi: http://dx.doi. org/10.1108/02621710810895677.

25. Nwokah, N. G., Ahiauzu, A. I. (2009). Emotional Intelligence and Marketing Effectiveness // Marketing Intelligence \& Planning. Vol. 7, Issue 27, pp. 864-881. doi: http://dx.doi. org/10.1108/02634500911000199.
26. Ocean Tomo, LLC. (2011). Intangible Asset Market Value. Internet access: <http://www. oceantomo.com/productsandservices/ investments/intangible-market-value $>$, [accessed January 14, 2014].

27. Pramaniak, R., Prakash G. (2010). Marketable Surplus and Marketing Efficiency of Vegetables in Indore District // The IUP Journal of Agricultural Economics. 7(3), pp. 84-93. Internet access: $<$ http://www.iupindia.in/710/IJAGE_Marketable_ Surplus_84.html>, [accessed January 29, 2014].

28. Rust, R. T., Ambler, T., Carpenter, G. S., Kumar, N., Srivastava, R. K. (2004). Measuring Marketing Productivity: Current Knowledge and Future Directions // Journal of Marketing. Vol. 68, pp. 76-89. doi: http://dx.doi.org/10.1509/ jmkg.68.4.191.42729.

29. Shaw, R., Merrick, D. (2005). Marketing Payback: Is Your Marketing Profitable? - London: Prentice Hall Financial Times.

30. Sheth, J. N., Sisodia, R. S. (2002). Marketing Productivity: Issues and Analysis // Journal of Business Research. Vol. 55, Issue 5, pp. 349-362. doi: http://dx.doi.org/10.1016/S0148-2963(00)00164-8.

31. Smit, E. G., Neijens, P. C. (2011). The March of Reliable Metrics: A Half-Century of Coming Closer to the Truth // Journal of Advertising Research. Vol. 51, No. 1, 50 ${ }^{\text {th }}$ Anniversary Supplement. Internet access: <http://www.warc.com/ Home.aspx>, [accessed February 10, 2014].

32. Statistical Enterprise Register (2014). Annual Statistical Data: Number of Enterprises. Internet access: <http://data.csb.gov.lv/Table. aspx?layout=tableViewLayout1\&px_tableid=SR0011. px\&px_path=uzreg_Ikgad\%C4\%93jie\%20statistikas\%20dati_01_skaits\&px_language $=e n \& p x$ $\mathrm{db}=$ uzreg\&rxid=09cbdccf-2334-4466-bdf7-0051bad1decd $>$, [accessed February 26, 2014].

The paper submitted: May 9, 2014 Prepared for publication: June 5, 2014

Jeḷena ŠALKOVSKA, Elīna OGSTA

\section{KIEKYBINIAI IR KOKYBINIAI IQMONIU RINKODAROS RODIKLIỤ VERTINIMO METODAI}

\section{S a n t r a u k a}

Pastaruosius kelis dešimtmečius rinkodaros veiklos vertinimas buvo labai aktuali tema rinkos tyrimuose, daugelis autorių ir mokslininkų didelị dėmesi skiria rinkodaros rodikliams ir praktiniam jų ịverti- nimui verslo planavimo ir rinkodaros igyvendinimo procesuose. Pripažįstama, kad rinkodaros strategija turi reaguoti ì nepastovią verslo aplinką ir konkurencijos sąlygas, todèl ịvertinimas, kontrolè ir tin- 
kamai pasirinkti veiklos vertinimo metodai padeda išlaikyti tinkamą strategiją ir parodo, kada pakeitimai yra reikalingi. Itvairūs rinkodaros rodikliai, kaip priemonès, leidžiančios ịvertinti rinkodaros poveikị visam verslui, turi būti naudojami vadovybès, siekiant nustatyti priežastinius ryšius tarp rinkodaros veiklos ir finansinès grąžos. Vienas iš svarbiausių strateginio verslo planavimo, valdymo ir kontrolès proceso aspektų yra matavimo metodai, naudojami rinkodaros efektyvumo ir rinkodaros veiklos vertinimui, tačiau pastebima, kad ịmonès dažnai nèra linkusios dalintis savo rinkodaros veiklos vertinimo patirtimi, todèl rinkodaros rodiklių naudojimas turi būti j̨vertinamas kokybiniais ir kiekybiniais vertinimo metodais.

Mokslinè tyrimo problema apima tai, kad rinkodaros vadybininkams ir rinkodaros specialistams Latvijos įmonèse trūksta žinių ir priemonių ivvertinti ir pranešti apie rinkodaros rezultatus, taip pat daugeliui iš jų sunku nustatyti, kurie rinkodaros rodikliai yra tinkamiausi. Vienas iš veiksnių, kuris labai apsunkina rinkodaros rodiklių atrinkimą i̇monèse, yra tai, kad nèra visuotinai priimto rinkodaros rodiklių matavimo rinkinio. Šiuo metu, verslo ir rinkodaros aplinka yra apibūdinama, kaip globali, dinamiška ir nuolat besikeičianti, todèl gebejimas ivertinti rinkodaros veiksmingumą ir efektyvumą yra labai svarbus siekiant sèkmingo verslo ir ilgalaikès plètros. O žinių trūkumas (kaip išmatuoti rinkodaros poveikį; kaip ịvertinti visus svarbius aspektus, kurie lemia vartotojų požiūrị ir ịsitikinimus, bei turi dideli poveikị jų pirkimo ir vartojimo sprendimams) gali padaryti įmonę labiau pažeidžiamą konkurencingoje rinkos aplinkoje. Siekiant pagerinti strateginę, ilgalaikę immonès orientaciją, autoriai siūlo įmonèms plètoti individualius, kiekvienai labiausiai tinkančius, rinkodaros rodiklių vertinimo metodus.

Atsižvelgiant ị visus aukščiau aptartus aspektus bei mokslinèje literatūroje aptariamus skirtingus požiūrius ị rinkodaros rodiklių, rinkodaros efektyvumo ir veiksmingumo vertinimą, šio tyrimo autoriai sukūrè konceptualų rinkodaros efektyvumo matavimo metodą. Autoriai bando kritiškai ịvertinti rinkodaros efektyvumo vertinimą, taip pat išanalizuoti rinkodaros rodiklių naudojimo praktiką Latvijos įmonèse, todèl $2014 \mathrm{~m}$. kovo mènesị buvo atliktas kiekybinis rinkodaros specialistų, vadovų ir šakos atstovų tyrimas, siekiant jivertinti rinkodaros rodiklių Latvijoje naudojimą. 